\title{
Transthoracic versus transhiatal esophagectomy
}

\author{
Przezklatkowe a przezrozworowe wycięcie przełyku
}

\author{
Mariusz Łochowski, Łukasz Pryt, Daniel Brzeziński, Józef Kozak \\ Oddział Kliniczny Chirurgii Klatki Piersiowej i Rehabilitacji Oddechowej, \\ Wojewódzki Szpital Specjalistyczny, Łódź
}

Kardiochirurgia i Torakochirurgia Polska 2012; 9 (4): 439-442

\begin{abstract}
Aim of the study: The aim of the present study is to compare patient qualification and treatment results for esophageal/cardia carcinoma patients treated with open transthoracic esophagectomy (TTE; McKeown) and with transhiatal esophagectomy (THE; Orringer).

Material and methods: We analyzed a group of 102 patients (24 women; 78 men; mean age 59.5 years) who underwent surgery for esophageal/cardia cancer in the years 2007-2011. We performed 38 transthoracic esophagectomies (TTE) and 64 transhiatal esophagectomies (THE). In all the cases, the conduit made from the stomach was moved through the posterior mediastinum and a two-field lymphadenectomy was performed with cervical anastomosis (employing the Collard method). Additionally, nutritional support was provided preoperatively (depending on the nutritional status of the patient) and postoperatively (to all patients).

Results: Patients qualified for TTE were at higher TNM stages of the disease, had tumors located in the proximal part of the esophagus, and had more concomitant diseases. The tumors were usually squamous cell carcinomas. For THE we qualified patients with lower TNM stages. The tumors were located closer to the cardia and were usually adenocarcinomas. We observed a higher volume of perioperative blood loss among the TTE group, who also required mechanical ventilation more frequently. Contrarily, in the THE group there were more intraoperative arrhythmias, postoperative pneumothoraces, and pleural effusions. We revealed no relationship between anastomotic leaks and operation type. Rather, they were related to malnutrition (albumin level). Anastomotic stenosis (stricture) was more frequent among the THE patients. Mean operative time was reduced in the THE group (150 $\mathrm{min}$ ) as compared to the TTE group (180 min).
\end{abstract}

Conclusions: 1 . Selecting the operative method for esophageal/cardia cancer patients depends on the stage of the disease and the location of the tumor. 2. Transhiatal operations are shorter in duration and put less strain on the patient, while

\section{Streszczenie}

Cel pracy: Porównanie doboru przypadków i wyników leczenia chorych z rakiem przełyku lub wpustu metodą otwartą - przezklatkową (McKeowna) z metodą przezrozworową (Orringera). Materiat i metody: W latach 2007-2011 radykalnie leczono 102 chorych na raka przełyku lub wpustu. Kobiet było 24, a mężczyzn 78; średnia wieku wynosiła 59,5 roku. Przeprowadzono 38 operacji przezklatkowych, a przezrozworowych 64. U wszystkich chorych konduit wykonany z żołądka przeprowadzano przez loże po przełyku, wykonywano limfadenektomię dwupolową i zespolenie mechaniczne na szyi sp. Collarda. W zależności od stanu odżywienia podawano przed zabiegiem i zawsze pooperacyjnie żywienie dojelitowe lub pozajelitowe. Wyniki: Pacjenci zakwalifikowani do operacji przezklatkowej znajdowali się w wyższym stopniu zaawansowania klinicznego choroby, guz położony był w bliższej części przełyku, częściej był to rak płaskonabłonkowy, u chorych tych występowało więcej chorób towarzyszących. Chorzy kwalifikowani do operacji przezrozworowej mieli niższy stopień zaawansowania klinicznego TNM, guz położony był bliżej wpustu i był to częściej rak gruczołowy. Chorzy po operacji przezklatkowej mieli większą okołooperacyjną utratę krwi i częściej wymagali respiratora, a u pacjentów po operacji przezrozworowej częściej występowały śródoperacyjne zaburzenia rytmu i wysięk lub odma opłucnowa. Nieszczelność zespolenia nie miała związku z rodzajem operacji, lecz ze stopniem niedożywienia. Zwężenia częściej wystąpiły po operacji przezrozworowej. Czas operacji przezklatkowej był o 0,5 godz. dłuższy od przezrozworowej (śr. 2,5 vs 3,0 godz.).

Wnioski: 1. Wybór zabiegu chirurgicznego w raku przełyku lub wpustu zależy od stopnia zaawansowania choroby i położenia guza. 2. Operacje przezrozworowe są krótsze, mniej obciążają chorego, chociaż obarczone są podobnym odsetkiem powikłań i śmiertelnością, natomiast operacje przezklatkowe charakteryzuje większa utrata krwi.

Słowa kluczowe: rak przełyku, operacja przezklatkowa, operacja przezrozworowa.

Address for correspondence: Mariusz Łochowski, Oddział Kliniczny Chirurgii Klatki Piersiowej i Rehabilitacji Oddechowej, Wojewódzki Szpital Specjalistyczny, ul. Pabianicka 62, 95-050 tódź , tel. +48 6027768 87, e-mail: marilo@op.pl 
transthoracic operations are characterized by increased blood loss. However, the complication and mortality rates are similar for both procedures.

Key words: esophageal carcinoma, transthoracic operation, transhiatal operation.

\section{Introduction}

There are many esophageal cancer surgery methods, the oldest of which is the transthoracic approach with thoracic anastomosis (the Lewis-Tanner approach) or cervical anastomosis (the McKeown approach). In the 1970s, Orringer introduced the transhiatal approach in order to diminish the number of cardiac and pulmonary complications resulting from thoracotomy. With the introduction of endoscopic methods (laparoscopy, thoracoscopy), surgeons began to employ minimally invasive procedures for esophagectomy [1, 2]. All these methods have their flaws and merits. In the present study, we wish to present our own experience related to the methods of transthoracic and transhiatal surgery and to qualifying patients for these procedures.

\section{Aim of the study}

The aim of this study is to compare patient qualification and treatment results for esophageal/cardia carcinoma patients treated with open transthoracic esophagectomy (TTE) and with transhiatal esophagectomy.

\section{Material and methods}

During the years 1996-2011, 1705 patients were treated for esophageal and cardia cancer. 273 patients (16\%) were treated radically, while the remaining 1432 were provided palliative care. Analysis was conducted on 102 patients (24 women, 78 men) aged 19-75 (mean - 59.5) who had been treated radically for esophageal/cardia cancer within the last 5 years. The patients did not receive neoadjuvant chemoradiotherapy. The examination of the patients qualified for surgery included history taking, physical examination, laboratory examination, contrast x-ray of the esophagus, endoscopic examination along with obtaining histopathological samples, thoracic and epigastric tomography, ultrasonography of the abdominal cavity and of the neck, bronchoscopy (neoplasms of the cervical as well as upper and middle thoracic esophagus).

Two types of surgery were performed on the patients: open surgery (McKeown approach) in 38 cases and transhiatal surgery (Orringer approach) in 64 cases.

Two-field lymphadenectomy was performed on the epigastrium and thorax.

The stomach was used as the esophageal substitute (conduit) for all patients. It was moved through the posterior mediastinum. The anastomosis of the proximal esophageal stump (ca. $2 \mathrm{~cm}$ ) with the conduit was performed by left-sided cervicotomy. The semi-mechanical technique (side-to-side Collard method) was employed in all patients.
A tube was inserted through the anastomosis to the conduit, introduced to the esophagus through the nose. A Redon drain was used for draining the vicinity of the anastomosis. A feeding jejunostomy was performed on the proximal segment of the small intestine. Most patients also underwent pyloromyotomy. Antithrombotic and antibacterial prophylaxis was conducted as well. During the first two postoperative days, the patients were provided with intravenous nutrition. Subsequently, enteral nutrition was provided using standard nutrition formulas.

Postoperatively (on the $6^{\text {th }}$ day), a contrast (Gastrografin ) radiological examination was conducted and the healing (tightness) of the cervical anastomosis was evaluated. In a later period (up to 3 years) its adequacy (width) was assessed.

The following factors that could influence treatment results were analyzed: age, nutritional status, presence of concomitant diseases, location of the tumor, perioperative blood loss, surgery duration, stage of the cancer, invasiveness of the procedure, presence of complications.

The examination results were noted in a Microsoft Excel spreadsheet (MS Office 2007) and were analyzed statistically with the chi-squared test, the Shapiro-Wilk test and the Mann-Whitney test. Statistically significant difference was set at $p<0.05$ for all statistical comparisons.

\section{Results}

Notwithstanding the difference in the number of patients, the compared groups undergoing the two procedures were homogeneous in terms of age, nutritional status and concomitant diseases (Tab. I).

The patients qualified for open transthoracic surgery were at more advanced TNM stages (63\% at stage III) and the tumor was located in the closer segment of the esophagus. The patients qualified for transhiatal surgery were at less advanced TNM stages (53\% at stage III) and the tumor was located closer to the cardia. The most frequent tumor type for transthoracic surgery was squamous carcinoma (84\% of cases), while the most frequent type of tumor for transhiatal surgery was adenocarcinoma (64\% of cases), which was statistically significant at $p<0.0001$ (Tab. I). Postoperative complications occurred in $42 \%$ of the patients, with different frequency in the two groups. The transthoracic surgery patients required a respirator more often, while the transhiatal surgery patients were more prone to intraoperative arrhythmias and pulmonary complications (pleural effusion or pneumothorax). The groups did not differ in terms of abdominal complications or mortality (Tab. III). The duration of transthoracic surgery was 30 min longer than in the case of transhiatal surgery (150 vs. 180 min on 
Tab. I. Comparison of patients qualified for transthoracic esophagectomy (TTE) with patients qualified for transhiatal esophagectomy (THE)

\begin{tabular}{|c|c|c|c|}
\hline Examined factor & $\begin{array}{c}\text { TTE } \\
(n=38)\end{array}$ & $\begin{array}{c}\text { THE } \\
(n=64)\end{array}$ & $\begin{array}{l}\text { TTE } / \text { THE } \\
p\end{array}$ \\
\hline mean age [years] & $58.8 \pm 8.4$ & $60.0 \pm 10.6$ & $\mathrm{~N} / \mathrm{A}$ \\
\hline body mass loss [kg/month] & $1.31 \pm 1.2$ & $3.86 \pm 1.0$ & $\mathrm{~N} / \mathrm{A}$ \\
\hline $\begin{array}{l}\text { albumin level in serum } \\
\text { [mg\%] }\end{array}$ & $3.76 \pm 0.59$ & $3.86 \pm 0.49$ & $\mathrm{~N} / \mathrm{A}$ \\
\hline $\begin{array}{l}\text { number of patients with } \\
\text { concomitant diseases }\end{array}$ & 24 & 50 & $\mathrm{~N} / \mathrm{A}$ \\
\hline $\begin{array}{l}\text { tumor location } \\
\text { cervical } \\
\text { upper thoracic } \\
\text { middle thoracic } \\
\text { lower thoracic } \\
\text { abdominal/cardia }\end{array}$ & $\begin{array}{c}- \\
4 \\
28 \\
6 \\
-\end{array}$ & $\begin{array}{c}- \\
- \\
- \\
16 \\
48\end{array}$ & $\begin{array}{l}- \\
- \\
- \\
-\end{array}$ \\
\hline $\begin{array}{l}\text { histological type } \\
\text { squamous carcinoma } \\
\text { adenocarcinoma }\end{array}$ & $\begin{array}{c}32 \\
6\end{array}$ & $\begin{array}{l}23 \\
41\end{array}$ & $<0.0001$ \\
\hline
\end{tabular}

Tab. II. Intraoperative complications among transthoracic esophagectomy (TTE) and transhiatal esophagectomy (THE) patients

\begin{tabular}{lccc} 
Examined factor & $\begin{array}{c}\text { TTE } \\
(n=38)\end{array}$ & $\begin{array}{c}\text { THE } \\
(n=64)\end{array}$ & $\begin{array}{c}\text { TTE/THE } \\
p\end{array}$ \\
$\begin{array}{l}\text { perioperative blood } \\
\text { loss [ml] }\end{array}$ & $461.18 \pm 335.6$ & $256.25 \pm 220.3$ & $<0.0001$ \\
\hline cardiac arrhythmias & 1 & 7 & N/A \\
\hline surgery duration [min] & 150 & 180 & N/A \\
\hline
\end{tabular}

average) (Tab. II). R0 resection was attained in 95\% of transthoracic surgery patients and in $86 \%$ of transhiatal surgery patients. R2 resection was only noted among transhiatal surgery patients $(6 \%)$. Statistically $(p<0.05)$, more lymph nodes were removed during the transthoracic surgery than during the transhiatal surgery (Tab. IV).

\section{Discussion}

For many years, the two most frequently used techniques for esophageal surgery were a matter of debate and controversy [2-4]. Patients with tumors located in the upper and middle thoracic esophagus require transthoracic surgery. Such tumors are typically at more advanced stages of the TNM classification and are rarely adenocarcinomas. Patients with tumors located in the lower thoracic esophagus and in the cardia qualify for transhiatal surgery. Such tumors exhibit less advanced TNM stages and are more frequently adenocarcinomas. Complication rates after esophagus surgery are estimated to reach as high as $81 \%$ [5]. In the material that we analyzed the percentage of complications was $44 \%$. Each technique has its own typical complications. Barghetto et. al., during a congress in Mexico in 2004, presented studies in which the percentages of complications after open surgery, transhiatal sur-
Tab. III. Postoperative complications among transthoracic esophagectomy (TTE) and transhiatal esophagectomy (THE) patients

\begin{tabular}{|c|c|c|c|c|}
\hline $\begin{array}{l}\text { Postoperative } \\
\text { complications }\end{array}$ & $\begin{array}{c}\text { TTE } \\
(n=38)\end{array}$ & $\begin{array}{c}\text { THE } \\
(n=64)\end{array}$ & $\begin{array}{c}\text { Total } \\
(n=102)\end{array}$ & $\begin{array}{c}\mathrm{TTE} / \mathrm{THE} \\
p\end{array}$ \\
\hline pulmonary & 2 & 9 & 11 & $\mathrm{~N} / \mathrm{A}$ \\
\hline cardiac & 1 & 7 & 8 & N/A \\
\hline abdominal & 1 & 1 & 2 & $\mathrm{~N} / \mathrm{A}$ \\
\hline $\begin{array}{l}\text { respiratory insuffi- } \\
\text { ciency (ICU) }\end{array}$ & 2 & 0 & 2 & - \\
\hline $\begin{array}{l}\text { damage to the re- } \\
\text { current laryngeal } \\
\text { nerve }\end{array}$ & 0 & 0 & 0 & - \\
\hline chylothorax & 0 & 0 & 0 & _- \\
\hline anastomotic leak & 4 & 5 & 9 & N/A \\
\hline $\begin{array}{l}\text { anastomotic stric- } \\
\text { ture }\end{array}$ & 3 & 8 & 11 & N/A \\
\hline mortality & 3 & 2 & 5 & N/A \\
\hline total & 13 (34\%) & 30 (47\%) & 43 (42\%) & N/A \\
\hline
\end{tabular}

Tab. IV. Oncological completeness among transthoracic esophagectomy (TTE) and transhiatal esophagectomy (THE) patients

\begin{tabular}{lccc} 
Examined factor & $\begin{array}{c}\text { TTE } \\
(n=38)\end{array}$ & $\begin{array}{c}\text { THE } \\
(n=64)\end{array}$ & $\begin{array}{c}\text { TTE/THE } \\
p\end{array}$ \\
$\begin{array}{l}\text { Number of lymph nodes } \\
\text { removed }\end{array}$ & $10 \pm 5$ & $8 \pm 4$ & $<0.05$ \\
\hline Resection & & & \\
R0 & $36(95 \%)$ & $55(86 \%)$ & \\
R1 & $2(5 \%)$ & $5(8 \%)$ & N/A \\
R2 & 0 & $4(6 \%)$ & \\
\hline TNM (simplified) & & & \\
I $^{\circ}$ & 1 & 5 & \\
$I^{\circ}$ & 13 & 25 & $\mathrm{~N} / \mathrm{A}$ \\
III $^{\circ}$ & 24 & 34 & \\
\hline
\end{tabular}

gery and minimally invasive surgery were $61 \%, 59 \%$, and $38 \%$, respectively [2]. The analysis of our material indicated a larger percentage of complications (47\%) for the transhiatal method. An opposite relationship was presented by Donohoe in a study published this year [6]. In this analysis of transthoracic and transhiatal operations, based on 584 cases, there was a higher percentage of complications for open surgery $(44.2 \%)$ than for transhiatal surgery (31.6\%). Respiratory disturbance is more common in the case of transthoracic operations, while cardiac arrhythmias, pneumothoraces and pleural effusions are more frequent in the case of transhiatal operations [7-9]. Orringer demonstrated intraoperative pleural damage in as many as $75 \%$ of patients [10]. In our material, we noted only four cases of pneumothorax after transhiatal surgery (6.3\%). The frequency of damage to the recurrent laryngeal nerve is estimated at $7 \%$ and it is more common in the case of the transhiatal approach $[5,10]$. In our material, there were no cases of damage to the recurrent laryngeal nerve, due to carefully conducted dissections (particularly cervical ones). We also did not note any cases of chylothorax, which is es- 
timated at $1-3 \%$ of complications in the medical literature $[2,10]$. Many studies have demonstrated increased blood loss in the case of open operations [5, 11, 12]. The examination conducted by our medical center demonstrated a statistically significant difference $(p<0.0001)$ in blood loss during open surgery. Blood loss during the operation may result in secondary ischemia of the anastomosis. As early as 20 years ago, Devar demonstrated the influence of this phenomenon on the frequency of occurrence of leaks and secondary strictures in the cervical esophagogastric anastomosis [13]. A similar relationship was noted in another, earlier study, which we conducted at our medical center. Patients with anastomotic leaks exhibited a statistically significant $(p<0.01)$ increase in blood loss during the procedure [14]. Some authors list better access to mediastinal lymph nodes among the advantages of the transthoracic procedure $[1,8]$. In our study, we demonstrated a significantly $(p<0.05)$ larger number of lymph nodes being removed in the transthoracic procedures. The duration of both procedures that we conducted was similar and was 150 and 180 minutes for the transthoracic and for the transhiatal approach, respectively. When minimally invasive methods are employed, the duration of the procedure is significantly increased (up to $400 \mathrm{~min}$ ) [5, 12].

\section{Conclusions}

Selecting the proper surgical procedure for cancer of the esophagus/cardia depends on the stage of the disease and on the location of the tumor. Transhiatal operations are shorter and put less strain on the patient, while transthoracic operations are characterized by increased blood loss. However, the complication and mortality rates are similar for both procedures.

The work was presented at the Congress of the Polish Society of Cardiothoracic Surgeons, 24-26.05.2012, Krakow, Poland.

\section{Literature}

1. Barreto JC, Posner MC. Transhiatal versus transthoracic esophagectomy for esophageal cancer. World I Gastroenterol 2010; 16: 3804-3810.

2. Braghetto A, Cesendes A, Cardemil G, Budiles P, Korn O, Valladares H. Open transtoracic or transhiatal esophagectomy versus minimally invasive esophagectomy in terms of morbidity mostality and survival. 9th World Congress of Endoscopic Surgery Mexico 2004.

3. Rentz J, Bull D, Harpole D, Bailey S, Neumayer L, Pappas T, Krasnicka B, Henderson W, Daley J, Khuri S. Transthoracic versus transhiatal esophagectomy. A prospective study of 945 patients. J Thorac Cardiovasc Surg 2003; 125: 1114-1120.

4. Yannopoulos $P$, Theodoridis P, Manes K. Esophagectomy without thoracotomy: 25 years of experience over 750 patients. Langenbecks Arch Surg 2009; 394: 611-616.

5. Perry KA, Enestvedt CK, Pham T, Welker M, Jobe BA, Hunter JG, Sheppard BC. Comparison of laparoscopic inversion esophagectomy and open transhiatal esophagectomy for high-grade dysplasia and stage I esophageal adenocarcinoma. Arch Surg 2009; 144: 679-684.

6. Donohoe CL, O'Farrell NJ, Ravi N, Reynolds JV. Evidence-based selective application of transhiatal esophagectomy in a high-volume esophageal center. World J. Surg 2012; 36: 98-103.

7. Colvin H, Dunning J, Khan OA. Transthoracic versus transhiatal esophagectomy for distal esophageal cancer: which is superior? Interact Cardio Vasc Surg 2011; 12: 265-269.

8. Davies AR, Forshaw MJ, Khan AA, Noorani AS, Patel VM, Strauss DC, Mason RC. Transhiatal esophagectomy in a high volume institution. World J Surg Onkol 2008; 6: 88-96.

9. Paç M, Başoglu A, Koçak H, Yekeler I, Yediyildiz S, Aydin NE, Yilmaz A, Okçu N, Keles M. Transhiatal versus transtoracic esophagectomy for esophageal cancer. J Thorac Cardiovasc Surg 1993; 106: 205-209.

10. Orringer MB, Marshall B, Chang AC, Lee J, Pickens A, Lau CL. Two thousand transhiatal esophagectomies: changing trends, lessons learned. Ann Surg 2007; 246: 363-374.

11. Hulscher JB, van Sandick JW, de Boer AG, Wijnhoven BP, Tijssen JG, Fockens P, Stalmeier PF, ten Kate FJ, van Dekken H, Obertop H, Tilanus HW, van Lanschot JJ. Extended transthoracic resection compared with limited transhiatal resection for adenocarcinoma of the esophagus. N Engl J Med 2002; 347 : 1662-1669.

12. Dapri G, Himpens J, Cadière GB. Minimally invasive esophagectomy for cancer: laparoscopic transhiatal procedure or thoracoscopy in prone position followed by laparoscopy? Surg Endo 2008; 22: 1060-1069.

13. Dewar L, Gelfand G, Finley RJ, Evans K, Inculet R, Nelems B. Factors affecting cervical anastomotic leak and stricture formation following esophagogastrectomy and gastric tube interposition. Am J Surg 1992; 163; 484-489.

14. Łochowski M. Czynniki ryzyka wystąpienia powikłań po wykonaniu zespoleń przełykowo-żołądkowych i przełykowo-jelitowych na szyi po wycięciu raka płaskonabłonkowego przełyku. Rozprawa doktorska, tódź 2008; 103. 